\title{
Enterobacter arachidis sp. nov., a plant-growth- promoting diazotrophic bacterium isolated from rhizosphere soil of groundnut
}

\author{
Munusamy Madhaiyan, ${ }^{1,2}$ Selvaraj Poonguzhali, ${ }^{1}$ Jung-Sook Lee, ${ }^{3}$ \\ Venkatakrishnan Sivaraj Saravanan, ${ }^{4}$ Keun-Chul Lee ${ }^{3}$ \\ and Palani Santhanakrishnan ${ }^{1}$
}

Correspondence

Munusamy Madhaiyan

mmadhaiyan@hotmail.com

\author{
${ }^{1}$ Department of Agricultural Microbiology, Tamilnadu Agricultural University, Coimbatore 641 003, \\ Tamilnadu, India \\ ${ }^{2}$ Biomaterials and Biocatalysts Group, Temasek Life Sciences Laboratory, 1 Research Link, \\ The National University of Singapore, Singapore 117604 \\ ${ }^{3}$ Korean Collection for Type Cultures (KCTC), Biological Resource Center (BRC), Korea Research \\ Institute of Bioscience and Biotechnology (KRIBB), 111 Gwahangno, Yusong-gu, Daejeon 305- \\ 806, Republic of Korea \\ ${ }^{4}$ Department of Microbiology, Indira Gandhi College of Arts and Science, Pondicherry University, \\ Kathirkamam, Pondicherry 605 009, India
}

\begin{abstract}
A methylotrophic nitrogen-fixing bacterial strain, $A h-143^{\top}$, isolated from the rhizosphere soil of field-grown groundnut was analysed by a polyphasic taxonomic approach. Comparative 16S rRNA gene sequence analysis combined with $r p o B$ gene sequence analysis allocated strain $\mathrm{Ah}-143^{\top}$ to the family Enterobacteriaceae, with Enterobacter radicincitans and Enterobacter cowanii as the closest relatives. The strain is Gram-stain-negative, non-spore-forming, aerobic and motile, having straight rod-shaped cells with a DNA G $+\mathrm{C}$ content of approximately $53.2 \mathrm{~mol} \%$. The strain utilizes methanol as a carbon source and the $m x a F$ gene was closely related to the $m x a F$ gene of members of the genus Methylobacterium. The fatty acid profile consisted of $\mathrm{C}_{16: 0}, \mathrm{C}_{17: 0}$ cyclo, $\mathrm{C}_{18: 1} \omega 7 \mathrm{c}$, summed feature 2 (iso- $\mathrm{C}_{16: 1} \mathrm{I}$ and/or $\mathrm{C}_{14: 0} 3-\mathrm{OH}$ ) and summed feature 3 (iso- $\mathrm{C}_{15: 0} 2-\mathrm{OH}$ and/or $\mathrm{C}_{16: 1} \omega 7 \mathrm{c}$ ) as the major components. DNA-DNA relatedness of strain $A h-143^{\top}$ with its close relatives was less than $20 \%$. On the basis of the phylogenetic analyses, DNA-DNA hybridization data, and unique physiological and biochemical characteristics, it is proposed that the strain represents a novel species of the genus Enterobacter and should be named Enterobacter arachidis sp. nov. The type strain is Ah-143 ${ }^{\top}(=\mathrm{NCIMB}$ $14469^{\top}=$ KCTC $22375^{\top}$ ).
\end{abstract}

The genus Enterobacter is clearly separated from other groups, forming a distinct branch, and at the time of writing included 22 species with validly published names (http://www.bacterio.cict.fr/e/enterobacter.html), Enterobacter cloacae being the type species (Hormaeche \& Edwards, 1960). Members of the genus Enterobacter are detected in

\footnotetext{
Abbreviation: ACCD, 1-aminocyclopropane-1-carboxylate deaminase.

The GenBank/EMBL/DDBJ accession numbers for the 16S rRNA, rpoB, nifH and $m \times a F$ gene sequences of strain $A h-143^{\top}$ are EU672801, FJ768683, FJ460712 and EU912491, respectively.

Phase-contrast and scanning electron micrographs of cells of strain Ah$143^{\top}$, phylogenetic trees based on rpoB and nifH gene sequences, and cellular fatty acid compositions of strain $\mathrm{Ah}-143^{\top}$ and related species of the genus Enterobacter are available with the online version of this paper.
}

various environments, such as infant formula (Stephan et al., 2007, 2008), clinical specimens (Brenner et al., 1986; Hoffmann et al., 2005) and in association with plants (Egamberdieva et al., 2008; Kämpfer et al., 2005). Several species of the genus Enterobacter are known to interact and exert beneficial effects on plant growth. The plant-growthpromoting effects of beneficial bacteria may occur through direct or indirect mechanisms that include production of phytohormones or enzymes that promote plant growth, increased nutrient uptake, and prevention of deleterious phytopathogens (Glick et al., 1999; Whipps, 2001). The complex mixture of carbohydrates, amino acids, organic acids and other nutrients released from seeds and roots are thought to support the growth of beneficial bacteria such as E. cloacae in the spermosphere and rhizosphere. E. cloacae colonizes the spermospheres and rhizospheres of a number 
of plant species and also suppresses Pythium ultimuminduced damping-off of seeds and seedlings of cucumber and other crops (Roberts et al., 2009). Similarly, other species of the genus Enterobacter have been reported to exhibit plant-growth-promoting effects that include production of phytohormones, fixation of atmospheric nitrogen and biocontrol activity (Ruppel et al., 1992; Ruppel \& Merbach, 1997; Götz et al., 2006). Further, application of species of the genus Enterobacter to plants has improved phosphate uptake and stimulated plant mycorrhization (Vassileva et al., 1999). In this paper, we include the formal taxonomic description of strain Ah$143^{\mathrm{T}}$, a novel species of the genus Enterobacter isolated from rhizosphere soil of groundnut, which exhibits extensive plant-growth-promoting activities such as production of phytohormones and 1-aminocyclopropane-1carboxylate deaminase (ACCD) and fixation of atmospheric nitrogen. The name Enterobacter arachidis sp. nov. is proposed.

Strain $\mathrm{Ah}-143^{\mathrm{T}}$ was isolated from rhizosphere soil of groundnut (Arachis hypogaea L. 'ALR-2') collected from Tamilnadu Agricultural University experimental plot, Coimbatore, India, on selective ammonium mineral salts (AMS) medium (Whittenbury et al., 1970) supplemented with filter-sterilized cycloheximide $\left(10 \mu \mathrm{g} \mathrm{ml}^{-1}\right)$ and $0.5 \%$ (v/v) methanol at $28{ }^{\circ} \mathrm{C}$ by the serial dilution technique. Cells were maintained on nutrient agar (NA, Difco) with $1 \%(\mathrm{v} / \mathrm{v})$ methanol, or on R2A medium with $0.5 \%(\mathrm{v} / \mathrm{v})$ methanol. Determination of morphological properties was performed using standard procedures (Gerhardt et al., 1994). Gram staining was performed by using a Gram staining kit (Difco), and bacterial suspensions were examined by phase-contrast microscopy for cell morphology and motility. Motility test agar (nutrient broth with $0.5 \%$ glucose and $0.5 \%$ agar) and motility test medium (Edwards \& Ewing, 1972) were also used. Preparation and examination of cells under a scanning electron microscope (SEM) were carried out according to Bozzola \& Russell (1998) and the cells were visualized using a Hitachi S-2500C SEM with GEMINI column equipped with a field-emission electron source. Cells of strain Ah-143 were Gram-stain-negative, straight rods and motile (Supplementary Fig. S1, available in IJSEM Online).

Nutritional features were determined using Biolog GN2 Microplates (Madhaiyan et al., 2007a) and carbon-source utilization tests (excluding Biolog) were performed using standard protocols (Green \& Bousfield, 1982). Antibiotic resistance and heavy metal tolerance of the strain was determined (Chanprame et al., 1996; Tan et al., 1999; Madhaiyan et al., 2007b). The strain was catalase-positive, and negative or weakly positive for oxidase. The nutritional and physiological characteristics of strain $\mathrm{Ah}-143^{\mathrm{T}}$ are given in the species description. Strain Ah- $143^{\mathrm{T}}$ was able to utilize methanol as a carbon source, which differentiated it from other close relatives. Furthermore, the strain utilized arabitol and L-fucose while other species showed weak or no growth (Table 1).
Strain Ah- $143^{\mathrm{T}}$ was screened for different plant-growthpromoting characteristics, such as the production of indole-3-acetic acid (IAA) and siderophores, ACCD activity and sulfur oxidation, through plate and quantitative assays using previously described procedures (Poonguzhali et al., 2006; Madhaiyan et al., 2006). Nitrogenase activity was estimated by using an acetylene reduction assay (Poonguzhali et al., 2006). Strain Ah-143 ${ }^{\mathrm{T}}$ possessed ACCD activity when examined through plate assays, but was negative for sulfur oxidation and siderophore production. The ACCD activity of the cell-free extracts was $7.85 \mathrm{nmol} \alpha$-ketobutyrate (mg protein $)^{-1} \mathrm{~h}^{-1}$ and the IAA production and nitrogenase activity were $5.57 \mu \mathrm{g} \mathrm{ml}^{-1}$ and $203.6 \mathrm{nmol} \mathrm{C}_{2} \mathrm{H}_{4}(\mathrm{mg} \text { protein })^{-1} \mathrm{~h}^{-1}$, respectively. Furthermore, in experiments using growth pouches (cyg seed germination pouch, Mega International), seed inoculation with strain $\mathrm{Ah}-143^{\mathrm{T}}$ significantly increased the root length of Indian mustard, tomato and rice by $61.1,21.6$ and $10.4 \%$, respectively, when compared with uninoculated controls. Strain Ah$143^{\mathrm{T}}$ produced methanol dehydrogenase at $34.16 \mathrm{nmol}$ $\min ^{-1}$ (mg protein $)^{-1}$ when the enzyme was estimated quantitatively according to Dunfield et al. (2003).

Chromosomal DNA from strain Ah- $143^{\mathrm{T}}$ was extracted by using the QIAamp DNA mini kit (Qiagen) and amplified using the universal primers 27F and 1492R (Madhaiyan et al., 2009). The partial gene sequence was determined by the fluorescent dye terminator method using the ABI prism Big dye terminator cycle sequencing ready reaction kit v.3.1 and products were run on an ABI3730XL capillary DNA sequencer (ABI Prism 310 Genetic Analyzer). The resultant $16 \mathrm{~S}$ rRNA gene sequence was compared with sequences from representative organisms of the same and related genera from the GenBank database and was aligned by using Clustal W (Thompson et al., 1994). Phylogenetic relationships were determined by the neighbour-joining method (Saitou \& Nei, 1987) using the software package MEGA 3.1 (Kumar et al., 2004). Bootstrap confidence values were obtained using 1000 resamplings. The $16 \mathrm{~S}$ rRNA gene sequence analysis showed that strain $\mathrm{Ah}-143^{\mathrm{T}}$ was phylogenetically affiliated to the genus Enterobacter within the Gammaproteobacteria, with the highest sequence similarity (97.2-98.7\%) with Enterobacter radicincitans, Enterobacter cloacae subsp. cloacae, Enterobacter cloacae subsp. dissolvens and Enterobacter cowanii (Fig. 1). However, based on $16 \mathrm{~S}$ rRNA gene sequence analysis alone, the novel strains cannot be allocated unequivocally to a narrower taxonomic level within the family Enterobacteriaceae and hence $r p o B$ gene sequence analysis was performed for species discrimination (Mollet et al., 1997; Drancourt et al., 2001; Li et al., 2004; Kämpfer et al., 2005). For analysis of $r p o B$ sequence, total DNA was prepared according to Niemann et al. (1997) and the gene was amplified and sequenced following the protocol of Mollet et al. (1997). Sequence comparison and phylogenetic analysis were carried out as mentioned earlier. The highest $r p o B$ sequence similarities were obtained with $E$. radicincitans (97.8\%), E. cowanii (95.8\%) and Enterobacter 
Table 1. Major characteristics that allow differentiation among members of the genus Enterobacter

Taxa: 1, Enterobacter arachidis sp. nov.; 2, E. cloacae subsp. cloacae; 3, E. cloacae subsp. dissolvens; 4, E. radicincitans; 5, E. cowanii; 6, E. cancerogenus; 7, E. asburiae; 8, E. turicensis; 9, E. helveticus; 10, E. gergoviae; 11, E. kobei; 12, E. hormaechei; 13, E. pyrinus; 14, E. ludwigii; 15, E. pulveris; 16, E. aerogenes; 17, E. nimipressuralis, 18, E. amnigenus biovar 1; 19, E. amnigenus biovar 2. Data in columns 1-10 from this study. Data in columns 10-17 from Izard et al. (1981), Hoffmann et al. (2005), Kämpfer et al. (2005) and Stephan et al. (2007, 2008). The percentage of strains giving a positive result is scored as:,$- 0-10 \% ;-/+, 10-20 \%$, v, 20-80\%; +/-, 80-90\%; +, 90-100\%. ND, No data available; SR, straight rods; CR, coccoid rods; $R$, rods.

\begin{tabular}{|c|c|c|c|c|c|c|c|c|c|c|c|c|c|c|c|c|c|c|c|}
\hline Characteristic & 1 & 2 & 3 & 4 & 5 & 6 & 7 & 8 & 9 & 10 & 11 & 12 & 13 & 14 & 15 & 16 & 17 & 18 & 19 \\
\hline Cell shape & SR & $\mathrm{R}$ & $\mathrm{R}$ & $\mathrm{R}$ & $\mathrm{R}$ & SR & $\mathrm{R}$ & $\mathrm{CR}$ & $\mathrm{CR}$ & $\mathrm{R}$ & $\mathrm{R}$ & $\mathrm{R}$ & SR & $\mathrm{R}$ & $\mathrm{CR}$ & $\mathrm{R}$ & $\mathrm{R}$ & SR & SR \\
\hline Aesculin hydrolysis & - & - & $-1+$ & + & + & + & + & + & + & + & - & - & + & $-1+$ & + & + & + & + & + \\
\hline Arginine dihydrolase & + & + & + & $\mathrm{V}$ & + & + & $\mathrm{V}$ & - & - & - & + & $\mathrm{V}$ & - & + & - & - & $\mathrm{V}$ & - & V \\
\hline Ornithine decarboxylase & + & + & + & - & - & + & + & - & - & + & + & + & + & + & - & + & - & $\mathrm{V}$ & + \\
\hline Voges-Proskauer test & + & + & + & + & + & + & - & - & - & + & + & + & $\mathrm{V}$ & + & - & + & + & + & + \\
\hline \multicolumn{20}{|l|}{ Carbon source utilization } \\
\hline Sucrose & + & + & + & + & + & - & + & - & - & + & + & + & + & + & + & + & - & + & - \\
\hline Citrate & + & + & + & + & + & + & + & - & - & + & + & + & - & + & - & + & $\mathrm{ND}$ & + & + \\
\hline Sorbitol & + & + & + & + & + & - & $+1-$ & - & - & - & + & - & - & + & - & + & + & - & + \\
\hline L-Fucose & + & - & $\mathrm{V}$ & - & - & + & - & - & - & $\mathrm{V}$ & - & + & - & V & - & - & - & - & ND \\
\hline L-Rhamnose & + & + & + & + & + & + & $+1-$ & + & + & + & + & + & + & + & + & + & + & + & + \\
\hline Putrescine & - & + & + & - & - & + & $-1+$ & - & + & $\mathrm{V}$ & $\mathrm{V}$ & - & + & - & $\mathrm{v}$ & $\mathrm{V}$ & - & - & - \\
\hline Mucate & - & $\mathrm{V}$ & + & - & + & + & $\mathrm{V}$ & + & + & - & V & v & - & + & + & + & + & $\mathrm{V}$ & + \\
\hline $\begin{array}{l}\text { 1-O-Methyl } \\
\alpha \text {-galactopyranoside }\end{array}$ & + & + & + & + & + & - & $+1-$ & + & + & + & + & - & - & + & + & $+1-$ & - & + & ND \\
\hline $\begin{array}{l}\text { 3-O-Methyl } \\
\text { D-glucopyranoside }\end{array}$ & - & - & - & - & - & + & - & - & - & - & - & $\mathrm{V}$ & - & $+1-$ & - & - & - & - & $\mathrm{ND}$ \\
\hline
\end{tabular}

turicensis $(86.9 \%)$ (Supplementary Fig. S2). The similarity values with the nearest neighbours were rather low, ranging from 91.4 to $97.8 \%$, when compared with the intraspecies similarity found within the family Enterobacteriaceae (Mollet et al., 1997), thus confirming a possibility that the strain might represent a novel species within the family Enterobacteriaceae.

The methanol dehydrogenase $(m x a F)$ gene required for methanol utilization and the nifH gene responsible for nitrogenase activity in strain $\mathrm{Ah}-143^{\mathrm{T}}$ were amplified from DNA extracts using the specific primer pairs mxaF f1003 and mxaF r1561 (McDonald \& Murrell, 1997), and 19F and 407R (Ueda et al., 1995), respectively. The products were sequenced directly and analysed as already mentioned. Analysis of the mxaF gene sequence (556 bp) from Ah- $143^{\mathrm{T}}$ revealed 99.4 and $94.1 \%$ gene sequence similarity with sequences from the type strains of Methylobacterium zatmanii and Methylobacterium lusitanum, respectively. The nifH gene (390 bp) from Ah- $143^{\mathrm{T}}$ was closely related to those of the strains of Serratia marcescens $(99.2 \%$ similarity) and Klebsiella pneumoniae (93.3\%), and other members of the family Enterobacteriaceae (Supplementary Fig. S3). Furthermore, PCR amplification was performed to determine the presence of the genes $m m o X$ (methane monooxygenase) and acdS (ACCD) in strain Ah-143 ${ }^{\mathrm{T}}$ using specific primer pairs mmoXB-1401b and mmoX-ms945f (Auman et al., 2000; Dedysh et al., 2005), and F1936 and F1939, respectively (Blaha et al., 2006). The results showed the presence of an expected $1230 \mathrm{bp}$ fragment for $m m o X$ and 558 bp fragment for ACCD (data not shown).

Fatty acid methyl ester analysis was carried out using a culture grown on tryptic soy agar [TSA, tryptic soy broth (Difco) with $1.5 \%$ agar] at $28{ }^{\circ} \mathrm{C}$ for $48 \mathrm{~h}$ and the Microbial Identification System (MIDI; Microbial ID), according to standard protocols (Sasser, 1990). Only those species located in the monophyletic group of close relatives with the new species and supported by a pairwise sequence similarity ranging from 97.0 to $98.7 \%$ were included in addition to the type species of the genus. The fatty acid profile of strain $\mathrm{Ah}-143^{\mathrm{T}}$ contained $\mathrm{C}_{16: 0}, \mathrm{C}_{18: 1} \omega 7 c$, summed feature 2 (iso- $\mathrm{C}_{16: 1} \mathrm{I}$ and/or $\mathrm{C}_{14: 0} 3-\mathrm{OH}$ ), summed feature $3\left(\mathrm{C}_{16: 1} \omega 7 c\right.$ and/or iso- $\left.\mathrm{C}_{15: 0} 2-\mathrm{OH}\right)$ and 


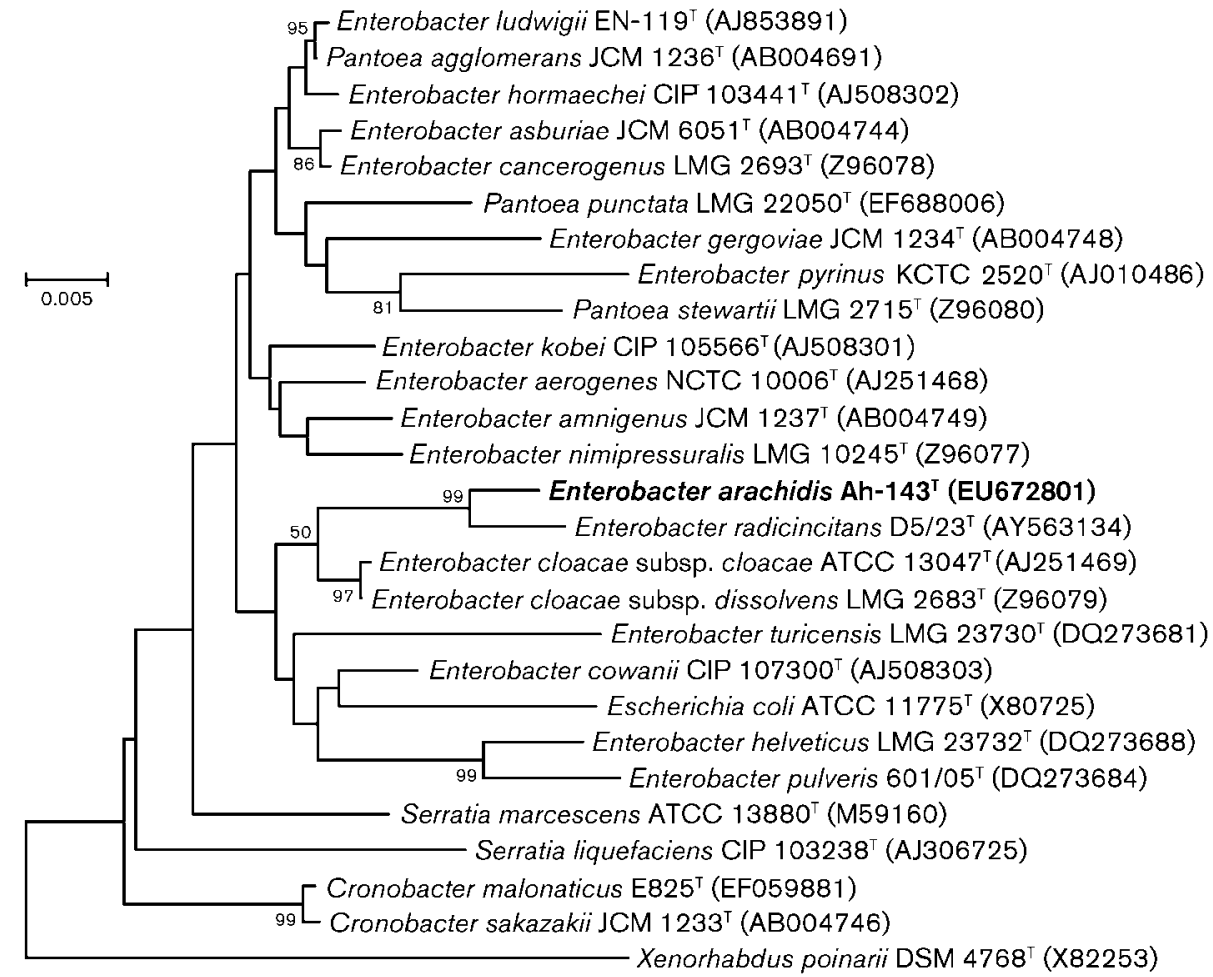

Fig. 1. Phylogenetic tree based on $16 \mathrm{~S}$ rRNA gene sequence comparison showing the position of strains belonging to the genus Enterobacter and other related genera. Numbers at nodes indicate percentages of occurrence in 1000 bootstrapped trees; only values greater than $50 \%$ are shown. Bar, 0.005 substitutions per nucleotide position.

$\mathrm{C}_{17: 0}$ cyclo as major constituents (Supplementary Table S1). DNA-DNA hybridization was carried out to determine the relatedness of strain $\mathrm{Ah}-143^{\mathrm{T}}$ with its closest relatives following the filter hybridization method (Seldin \& Dubnau, 1985). Hybridization temperature was $65{ }^{\circ} \mathrm{C}$ and DNA-DNA relatedness was quantified by using a densitometer (Bio-Rad). Probe labelling was conducted by using the non-radioactive DIG-High Prime system (Roche Diagnostics), and hybridized DNA was visualized using the DIG luminescent detection kit according to the manufacturer's instructions (Roche Diagnostics). Strain Ah- $143^{\mathrm{T}}$ showed a low level of DNA-DNA relatedness, less than $20 \%$, with its close relatives E. radicincitans (16\%), E. cloacae subsp. cloacae (12\%), E. cloacae subsp. dissolvens $(14 \%)$ and E. cowanii (19\%), indicating that the new isolate is genotypically different from these type strains. The $\mathrm{G}+\mathrm{C}$ content of genomic DNA was determined by HPLC analysis using a reverse-phase column (Supelcosil LC-18 S, Supelco) of individual nucleosides as described previously (Mesbah et al., 1989). The DNA G + C content of strain $\mathrm{Ah}-143^{\mathrm{T}}$ was $53.2 \mathrm{~mol} \%$, which falls within the range described for the genus Enterobacter (Richard, 1984; Inoue et al., 2000).

The 16S rRNA and $r p o B$ gene sequence similarity data and DNA-DNA hybridization values differentiated strain Ah$143^{\mathrm{T}}$ from other members of the genus Enterobacter.
Furthermore, the strain showed methylotrophic properties with an ability to utilize methanol and the mxaF gene was closely related to those of methylotrophic bacteria. Based on the recommendation of Wayne et al. (1987) and on the data presented here, it is concluded that strain Ah- $143^{\mathrm{T}}$ represents a novel species of the genus Enterobacter for which we propose the name Enterobacter arachidis sp. nov.

\section{Description of Enterobacter arachidis sp. nov.}

Enterobacter arachidis (a.ra.chi'dis. N.L. gen. n. arachidis, of Arachis, isolated from groundnut).

Cells are Gram-stain-negative, straight rods, motile, 0.5$0.7 \mu \mathrm{m}$ wide, $2.0-3.7 \mu \mathrm{m}$ long and occur singly or in pairs. Grows on AMS, TSA, R2A, NA+1\% methanol and MacConkey agar. Catalase-positive and weakly oxidasepositive. Grows in the presence of $0-5 \%(\mathrm{w} / \mathrm{v}) \mathrm{NaCl}$, but not in the presence of $6 \%(\mathrm{w} / \mathrm{v}) \mathrm{NaCl}$ or higher concentrations. Growth occurs between 20 and $30{ }^{\circ} \mathrm{C}$ with an optimum at $28{ }^{\circ} \mathrm{C}$. The $\mathrm{pH}$ range for growth is $\mathrm{pH} 4-10$, with optimal growth at $\mathrm{pH}$ 7. Starch hydrolysis is positive, but aesculin and gelatin hydrolysis are absent. Nitrate reduction is positive and indole production is negative. Positive for protease, lipase, pectinase, cellulase, ornithine decarboxylase and arginine dihydrolase enzymes and negative for urease. Positive for Voges-Proskauer and negative for methyl red tests. Able to tolerate and grow in the presence of 
$\mathrm{NiCl}_{2}$ or $\mathrm{CdCl}_{2}$ up to $1 \mathrm{mM}$ or $4 \mathrm{mM}$, respectively, when supplemented in the growth plates. Positive for utilization of dextrin, glycogen, Tween 40 , Tween $80, \mathrm{~N}$ acetyl-D-galactosamine, $\mathrm{N}$-acetyl-D-glucosamine, adonitol, L-arabinose, D-arabitol, cellobiose, i-erythritol, D-fructose, L-fucose, D-galactose, gentiobiose, $\alpha$-D-glucose, myo-inositol, lactose, lactulose, maltose, D-mannitol, D-mannose, methyl $\beta$-D-glucoside, 1-O-Methyl $\alpha$-galactopyranoside, D-psicose, raffinose, L-rhamnose, D-sorbitol, dulcitol, sucrose, trehalose, turanose, xylitol, pyruvic acid methyl ester, succinic acid monomethyl ester, acetic acid, cis-aconitic acid, citric acid, formic acid, D-galacturonic acid, D-gluconic acid, Dglucosaminic acid, D-glucuronic acid, $\alpha$-hydroxybutyric acid, $\beta$-hydroxybutyric acid, $\alpha$-ketoglutaric acid, DL-lactic acid, malonic acid, D-saccharic acid, succinic acid, bromosuccinic acid, glucuronamide, L-alaninamide, D-alanine, L-alanine, Lalanyl glycine, L-asparagine, L-aspartic acid, L-glutamic acid, glycyl L-aspartic acid, glycyl L-glutamic acid, L-histidine, Lornithine, L-proline, L-pyroglutamic acid, D-serine, L-serine, L-threonine, urocanic acid, inosine, uridine, thymidine, glycerol, DL- $\alpha$-glycerol phosphate, $\alpha$-D-glucose 1-phosphate and D-glucose 6-phosphate. The following compounds are not utilized as sole carbon sources: $\alpha$-cyclodextrin, Dmelibiose, putrescine, mucate, 3-O-methyl D-glucopyranoside, D-galactonic acid lactone, $\gamma$-hydroxybutyric acid, $p$ hydroxyphenylacetic acid, itaconic acid, $\alpha$-ketobutyric acid, $\alpha$-ketovaleric acid, propionic acid, quinic acid, sebacic acid, succinamic acid, L-hydroxyproline, L-leucine, L-phenylalanine, DL-carnitine, $\gamma$-aminobutyric acid, phenylethylamine, putrescine, 2-aminoethanol and 2,3-butanediol. The type strain is highly resistant (up to $500 \mu \mathrm{g} \mathrm{ml}^{-1}$ ) to bacitracin, penicillin $\mathrm{G}$, novabiocin and cephalosporin, but sensitive (lowest concentration tolerated) to spectinomycin $\left(25 \mu \mathrm{g} \mathrm{ml}^{-1}\right)$, carbenicillin $\left(500 \mu \mathrm{g} \mathrm{ml}^{-1}\right)$, kanamycin $\left(25 \mu \mathrm{g} \mathrm{ml}^{-1}\right)$, nalidixic acid $(25 \mu \mathrm{g}$ $\left.\mathrm{ml}^{-1}\right)$, chloramphenicol $\left(25 \mu \mathrm{g} \mathrm{ml}^{-1}\right)$, erythromycin $(50 \mu \mathrm{g}$ $\left.\mathrm{ml}^{-1}\right)$, polymyxin B $\left(25 \mu \mathrm{g} \mathrm{ml}^{-1}\right)$, rifampicin $\left(25 \mu \mathrm{g} \mathrm{ml}^{-1}\right)$, vancomycin $\left(500 \mu \mathrm{g} \mathrm{ml}^{-1}\right)$, trimethoprim $\left(25 \mu \mathrm{g} \mathrm{ml}^{-1}\right)$, cefotoxime $\left(125 \mu \mathrm{g} \mathrm{ml}^{-1}\right)$, doxycyclin $\left(125 \mu \mathrm{g} \mathrm{ml}^{-1}\right)$, ampicillin $\left(500 \mu \mathrm{g} \mathrm{ml}^{-1}\right)$, gentamicin $\left(250 \mu \mathrm{g} \mathrm{ml}^{-1}\right)$ and tetracycline $\left(25 \mu \mathrm{g} \mathrm{ml}^{-1}\right)$. The $m x a F$ and nifH genes for methanol dehydrogenase and nitrogenase activity, respectively, are present. The major fatty acids are $\mathrm{C}_{16: 0}, \mathrm{C}_{18: 1} \omega 7 c, \mathrm{C}_{17: 0}$ cyclo and summed features 2 (iso- $\mathrm{C}_{16: 1} \mathrm{I}$ and/or $\mathrm{C}_{14: 0} 3-\mathrm{OH}$ ) and $3\left(\mathrm{C}_{16: 1} \omega 7 c\right.$ and/or iso- $\left.\mathrm{C}_{15: 0} 2-\mathrm{OH}\right)$.

The type strain, Ah- $143^{\mathrm{T}}\left(=\mathrm{NCIMB} 14469^{\mathrm{T}}=\mathrm{KCTC}\right.$ $22375^{\mathrm{T}}$ ), was isolated from rhizosphere soil of groundnut (Arachis hypogaea L. 'ALR-2'), the sample being collected at the pod initiation stage from an experimental field, Tamilnadu Agricultural University (TNAU), Coimbatore, Tamilnadu, India. The DNA G $+\mathrm{C}$ content of the type strain is $53.2 \mathrm{~mol} \%$.

\section{Acknowledgements}

We wish to thank Professor Jean P. Euzéby for his valuable advice on nomenclature. This work was financially supported by the Indian Council of Agricultural Research (ICAR), New Delhi, India. The authors also acknowledge the financial support by grant from the KRIBB Research Initiative Program, Daejeon, Republic of Korea.

\section{References}

Auman, A. J., Stolyar, S., Costello, A. M. \& Lidstrom, M. E. (2000). Molecular characterization of methanotrophic isolates from freshwater lake sediment. Appl Environ Microbiol 66, 5259-5266.

Blaha, D., Prigent-Combaret, C., Mirza, M. S. \& Moënne-Loccoz, Y. (2006). Phylogeny of the 1-aminocyclopropane-1-carboxylic acid deaminase-encoding gene acdS in phytobeneficial and pathogenic Proteobacteria and relation with strain biogeography. FEMS Microbiol Ecol 56, 455-470.

Bozzola, J. J. \& Russell, L. D. (1998). Electron Microscopy: Principles and Techniques for Biologists, 2nd edn. Sudbury, MA: Jones \& Bartlett.

Brenner, D. J., McWhorter, A. C., Kai, A., Steigerwalt, A. G. \& Farmer, J. J., III (1986). Enterobacter asburiae sp. nov., a new species found in clinical specimens, and reassignment of Erwinia dissolvens and Erwinia nimipressuralis to the genus Enterobacter as Enterobacter dissolvens comb. nov. and Enterobacter nimipressuralis comb. nov. J Clin Microbiol 23, 1114-1120.

Chanprame, S., Todd, J. J. \& Widholm, J. M. (1996). Prevention of pink-pigmented methylotrophic bacteria (Methylobacterium mesophilicum) contamination of plant tissue cultures. Plant Cell Rep 16, 222225.

Dedysh, S. N., Knief, C. \& Dunfield, P. F. (2005). Methylocella species are facultatively methanotrophic. J Bacteriol 187, 4665-4670.

Drancourt, M., Bollet, C., Carta, A. \& Rousselier, P. (2001). Phylogenetic analyses of Klebsiella species delineate Klebsiella and Raoultella gen. nov., with description of Raoultella ornithinolytica comb. nov., Raoultella terrigena comb. nov. and Raoultella planticola comb. nov. Int J Syst Evol Microbiol 51, 925-932.

Dunfield, P. F., Khmelenina, V. N., Suzina, N. E., Trotsenko, Y. A. \& Dedysh, S. N. (2003). Methylocella silvestris sp. nov., a novel methanotroph isolated from an acidic forest cambisol. Int J Syst Evol Microbiol 53, 1231-1239.

Edwards, P. R. \& Ewing, W. H. (1972). Identification of Enterobacteriaceae, 3rd edn. Minneapolis: Burgess Publishing Co.

Egamberdieva, D., Kamilova, F., Validov, S., Gafurova, L., Kucharova, Z. \& Lugtenberg, B. (2008). High incidence of plant growth-stimulating bacteria associated with the rhizosphere of wheat grown on salinated soil in Uzbekistan. Environ Microbiol 10, $1-9$.

Gerhardt, P., Murray, R. G. E., Wood, W. A. \& Krieg, N. R. (editors) (1994). Methods for General and Molecular Bacteriology. Washington, DC: American Society for Microbiology.

Glick, B. R., Patten, C. L., Holguin, G. \& Penrose, D. M. (1999). Biochemical and Genetic Mechanisms used by Plant Growth Promoting Bacteria. London: Imperial College Press.

Götz, M., Gomes, N. C. M., Dratwinski, A., Costa, R., Berg, G., Peixoto, R., Mendonça-Hagler, L. \& Smalla, K. (2006). Survival of $g f p$-tagged antagonistic bacteria in the rhizosphere of tomato plants and their effects on the indigenous bacterial community. FEMS Microbiol Ecol 56, 207-218.

Green, P. N. \& Bousfield, I. J. (1982). A taxonomic study of some Gram-negative facultatively methylotrophic bacteria. J Gen Microbiol 128, 623-638.

Hoffmann, H., Stindl, S., Ludwig, W., Stumpf, A., Mehlen, A., Heesemann, J., Monget, D., Schleifer, K. H. \& Roggenkamp, A. (2005). Reassignment of Enterobacter dissolvens to Enterobacter cloacae as E. cloacae subspecies dissolvens comb. nov. and emended 
description of Enterobacter asburiae and Enterobacter kobei. Syst Appl Microbiol 28, 196-205.

Hormaeche, E. \& Edwards, P. R. (1960). A proposed genus Enterobacter. Int Bull Bacteriol Nomencl Taxon 10, 71-74.

Inoue, K., Sugiyama, K., Kosako, Y., Sakazaki, R. \& Yamai, S. (2000). Enterobacter cowanii sp. nov., a new species of the family Enterobacteriaceae. Curr Microbiol 41, 417-420.

Izard, D., Gavini, F., Trinel, P. A. \& Leclerc, H. (1981). Deoxyribonucleic acid relatedness between Enterobacter cloacae and Enterobacter amnigenus sp. nov. Int J Syst Bacteriol 31, 35-42.

Kämpfer, P., Ruppel, S. \& Remus, R. (2005). Enterobacter radicincitans sp. nov., a plant growth promoting species of the family Enterobacteriaceae. Syst Appl Microbiol 28, 213-221.

Kumar, S., Tamura, K. \& Nei, M. (2004). MEGA3: integrated software for molecular evolutionary genetics analysis and sequence alignment. Brief Bioinform 5, 150-163.

Li, X., Zhang, D., Chen, F., Ma, J., Dong, Y. \& Zhang, L. (2004). Klebsiella singaporensis sp. nov., a novel isomaltulose-producing bacterium. Int J Syst Evol Microbiol 54, 2131-2136.

Madhaiyan, M., Poonguzhali, S., Ryu, J. \& Sa, T. (2006). Regulation of ethylene levels in canola (Brassica campestris) by 1-aminocyclopropane1-carboxylate deaminase-containing Methylobacterium fujisawaense. Planta 224, 268-278.

Madhaiyan, M., Kim, B.-Y., Poonguzhali, S., Kwon, S.-W., Song, M.-H., Ryu, J.-H., Go, S.-J., Koo, B.-S. \& Sa, T.-M. (2007a). Methylobacterium oryzae sp. nov., an aerobic, pink-pigmented, facultatively methylotrophic, 1-aminocyclopropane-1-carboxylate deaminase-producing bacterium isolated from rice. Int J Syst Evol Microbiol 57, 326-331.

Madhaiyan, M., Poonguzhali, S. \& Sa, T. (2007b). Metal tolerating methylotrophic bacteria reduces nickel and cadmium toxicity and promotes plant growth of tomato (Lycopersicon esculentum L.). Chemosphere 69, 220-228.

Madhaiyan, M., Poonguzhali, S., Kwon, S.-W. \& Sa, T.-M. (2009). Methylobacterium phyllosphaerae sp. nov., a pink-pigmented facultative methylotroph from the phyllosphere of rice. Int J Syst Evol Microbiol 59, 22-27.

McDonald, I. R. \& Murrell, J. C. (1997). The methanol dehydrogenase structural gene $m x a F$ and its use as a functional gene probe for methanotrophs and methylotrophs. Appl Environ Microbiol 63, 32183224.

Mesbah, M., Premachandran, U. \& Whitman, W. B. (1989). Precise measurement of the $\mathrm{G}+\mathrm{C}$ content of deoxyribonucleic acid by highperformance liquid chromatography. Int J Syst Bacteriol 39, 159-167.

Mollet, C., Drancourt, M. \& Raoult, D. (1997). $r p o B$ sequence analysis as a novel basis for bacterial identification. Mol Microbiol 26, 10051011.

Niemann, S., Pühler, A., Tichy, H. V., Simon, R. \& Selbitschka, W. (1997). Evaluation of the resolving power of three different DNA fingerprinting methods to discriminate among isolates of a natural Rhizobium meliloti population. J Appl Microbiol 82, 477-484.

Poonguzhali, S., Madhaiyan, M. \& Sa, T. (2006). Cultivationdependent characterization of rhizobacterial communities from field grown Chinese cabbage Brassica campestris ssp pekinensis and screening of traits for potential plant growth promotion. Plant Soil 286, 167-180.
Richard, C. (1984). Genus VI. Enterobacter Hormaeche and Edwards 1960. In Bergey's Manual of Systematic Bacteriology, vol. 1, pp. 465469. Edited by N. R. Krieg \& J. G. Holt. Baltimore: Williams \& Wilkins.

Roberts, D. P., Baker, C. J., McKenna, L., Liu, S., Buyer, J. S. \& Kobayashi, D. Y. (2009). Influence of host seed on metabolic activity of Enterobacter cloacae in the spermosphere. Soil Biol Biochem 41, 754-761.

Ruppel, S. \& Merbach, W. (1997). Effect of ammonium and nitrate on ${ }^{15} \mathrm{~N}_{2}$-fixation of Azospirillum spp. and Pantoea agglomerans in association with wheat plants. Microbiol Res 152, 377-383.

Ruppel, S., Hecht-Buchholz, C., Remus, R., Ortmann, U. \& Schmelzer, R. (1992). Settlement of diazotrophic, phytoeffective bacterial strain Pantoea agglomerans on and within winter wheat: an investigation using ELISA and transmission electron microscopy. Plant Soil 145, 261-273.

Saitou, N. \& Nei, M. (1987). The neighbor-joining method: a new method for reconstructing phylogenetic trees. Mol Biol Evol 4, 406425.

Sasser, M. (1990). Identification of bacteria through fatty acid analysis. In Methods in Phytobacteriology, pp. 199-204. Edited by Z. Klement, K. Rudolph \& D. C. Sands. Budapest: Akademiai Kiado.

Seldin, L. \& Dubnau, D. (1985). Deoxyribonucleic acid homology among Bacillus polymyxa, Bacillus macerans, Bacillus azotofixans, and other nitrogen-fixing Bacillus strains. Int J Syst Bacteriol 35, 151-154.

Stephan, R., Van Trappen, S., Cleenwerck, I., Vancanneyt, M., De Vos, P. \& Lehner, A. (2007). Enterobacter turicensis sp. nov. and Enterobacter helveticus sp. nov., isolated from fruit powder. Int J Syst Evol Microbiol 57, 820-826.

Stephan, R., Van Trappen, S., Cleenwerck, I., Iversen, C., Joosten, H., De Vos, P. \& Lehner, A. (2008). Enterobacter pulveris sp. nov., isolated from fruit powder, infant formula and an infant formula production environment. Int J Syst Evol Microbiol 58, 237-241.

Tan, Z. Y., Wang, E. T., Peng, G. X., Zhu, M. E., Martínez-Romero, E. \& Chen, W. X. (1999). Characterization of bacteria isolated from wild legumes in the north-western regions of China. Int J Syst Bacteriol 49, 1457-1469.

Thompson, J. D., Higgins, D. G. \& Gibson, T. J. (1994). CLUSTAL W: improving the sensitivity of progressive multiple sequence alignment through sequence weighting, position-specific gap penalties and weight matrix choice. Nucleic Acids Res 22, 4673-4680.

Ueda, T., Suga, Y., Yahiro, N. \& Matsuguchi, T. (1995). Phylogeny of Sym plasmids of rhizobia by PCR-based sequencing of a nodC segment. J Bacteriol 177, 468-472.

Vassileva, M., Azcon, R., Barea, J.-M. \& Vassilev, N. (1999). Effect of encapsulated cells of Enterobacter sp on plant growth and phosphate uptake. Bioresour Technol 67, 229-232.

Wayne, L. G., Brenner, D. J., Colwell, R. R., Grimont, P. A. D., Kandler, O., Krichevsky, M. I., Moore, L. H., Moore, W. E. C., Murray, R. G. E. \& other authors (1987). International Committee on Systematic Bacteriology. Report of the ad hoc committee on reconciliation of approaches to bacterial systematics. Int J Syst Bacteriol 37, 463-464.

Whipps, J. M. (2001). Microbial interactions and biocontrol in the rhizosphere. J Exp Bot 52, 487-511.

Whittenbury, R., Phillips, K. C. \& Wilkinson, J. F. (1970). Enrichment, isolation and some properties of methane-utilizing bacteria. J Gen Microbiol 61, 205-218. 